\title{
New data on the earliest European ruminant (Mammalia, Artiodactyla): A revision of the fossil mandible from Rusce in the Pčinja basin (late Eocene, Southeastern Serbia)
}

\author{
Bastien Mennecart, Predrag Radović, and Zoran Marković
}

\begin{abstract}
A fragmented right branch of a ruminant mandible from Rusce (Pčinja basin, Serbia) was originally published in the first half the twentieth century as Micromeryx flourensianus, a small ruminant common in the middle Miocene of Europe. Based on this determination, sedimentary filling of the Pčinja basin was considered to be of late Miocene age. However, later paleobotanical and micromammalian studies pointed to a late Eocene age for these deposits. The redescription and discussion of the ruminant fossil mandible from Rusce led to the conclusion that the specimen may belong to a small species of Bachitheriidae, probably to Bachitherium thraciensis. This ruminant was originally only known from late Eocene strata in Bulgaria. The peculiar late Eocene faunal composition from the Balkans (e.g., rodents, perissodactyls, and ruminants) confirms that the "Balkanian High" was a distinct paleobiogeographical province from that of Western Europe until the Bachitherium dispersal event, which occurred during the early Oligocene ca. 31 Mya.
\end{abstract}

Bastien Mennecart. Naturhistorisches Museum Wien, Burgring 7, 1010 Wien, Austria; Naturhistorisches Museum Basel, Augustinergasse 2, 4001 Basel, Switzerland. mennecartbastien@gmail.com

Predrag Radović. Curator, National Museum Kraljevo, Trg Svetog Save 2, 36000, Kraljevo, Serbia.

pedja_radovic@yahoo.com

Zoran Marković. Museum adviser at Department of Paleontology, Natural History Museum, Njegoševa 51, Belgrade, Serbia. zoran.markovic@nhmbeo.rs

Keywords: Bachitherium; paleobiogeography; Balkans; Grande-Coupure; Bachitherium dispersal event

Submission: 30 April 2018 Acceptance: 18 October 2018

Mennecart, Bastien, Radović, Predrag, and Marković, Zoran. 2018. New data on the earliest European ruminant (Mammalia, Artiodactyla): A revision of the fossil mandible from Rusce in the Pčinja basin (late Eocene, Southeastern Serbia). Palaeontologia Electronica 21.3.38A 1-12. https://doi.org/10.26879/883

palaeo-electronica.org/content/2018/2339-eocene-ruminant-from-rusce

Copyright: November 2018 Paleontological Society.

This is an open access article distributed under the terms of Attribution-NonCommercial-ShareAlike 4.0 International (CC BY-NC-SA 4.0 ), which permits users to copy and redistribute the material in any medium or format, provided it is not used for commercial purposes and the original author and source are credited, with indications if any changes are made.

creativecommons.org/licenses/by-nc-sa/4.0/ 


\section{INTRODUCTION}

Ruminants are currently one of the most diverse clades of large herbivorous mammals with more than 200 species described from all over the world, and the reasons for their success may be linked to their complex stomach and the unique ruminating process (Groves and Grubb, 2011). However, very little is known about their origin. The first ruminant diversification event occurred in Asia during the middle Eocene (Archaeomerycidae and Lophiomerycidae) and then in North America (Leptomerycidae and Hypertragulidae) (Webb, 1998; Métais and Vislobokova, 2007). In contrast, recent studies confirm that ruminants reached Western Europe during the Oligocene Grande-Coupure dispersal event (Mennecart, 2012; Mennecart and Métais, 2015) and Africa during the early Miocene (Van der Made, 1999; Cote, 2010). Only scarce remains of Eocene large mammals are known from Eastern Europe and Western Asia, in contrast to the very abundant fossil record from Central Asia (mainly China and Mongolia) and Western Europe. Recent revisions of Perissodactyla from the Balkans highlighted the existence of a quite diversified latest Eocene Rhinocerotoidea fauna with Asian affinities (Mennecart et al., 2018) including the newly described Sellamynodon zimborensis (Tissier et al., 2018). However, no members of this fauna survived the Eocene-Oligocene boundary (Mennecart et al., 2018). While data on Eocene micromammals from the Balkan Peninsula are becoming more and more extensive (Marković et al., 2013, 2018; de Bruijn et al., 2018; Wessels et al., 2018; van der Weerd et al., 2018), ruminants are currently known only by one mandible found in a borehole in Sladun, Bulgaria (late Bartonian or early Priabonian; Mennecart et al., 2018). The recent description of this oldest ruminant from Europe (Bachitherium thracensis Mennecart, Geraads, Spassov, and Zagorchev, 2018) led to a new scenario for the pattern of dispersal events between Asia and Europe (Mennecart et al., 2018). Furthermore, this fossil is the only pre-GrandeCoupure ruminant known so far from Europe (Mennecart, 2012; Mennecart et al., 2018).

An additional ruminant fossil mandible comes from Rusce (i.e., between the villages Rusce and Buštranje), a village in the municipality of Vranje (Southeastern Serbia), and it was originally described by Laskarev (1939). He attributed the specimen to the moschid species Micromeryx flourensianus Lartet, 1851, mainly based on the small size of the specimen. However, the site is located within the Pčinja basin, well known for its Eocene, and possibly Oligocene, sedimentary fillings (de Bruijn et al., 2018). Thus, the mandible from Rusce most certainly comes from pre-Neogene deposits. Since the genus Micromeryx first appeared during the early Miocene (oldest fossil known is middle Orleanian or MN4, see Alaburić and Radović, 2016; the origin of the Moschidae is estimated to the earliest Miocene, see Sánchez et al., 2015 and Mennecart et al., 2017), Laskarev's taxonomical attribution of the specimen from Rusce seems highly unlikely. Unfortunately, the whereabouts of the original fossil are currently unknown. Nevertheless, considering the extremely poor fossil record of Paleogene ruminants from this part of Europe, we decided to re-examine the specimen based on the detailed published descriptions, measurements, photographs, and drawings (Laskarev, 1939).

Here we reassess the ruminant fossil specimen remain from Rusce. The new taxonomical attribution, associated to the Balkano-Anatolian late Eocene faunas, may confirm the "Bachitherium dispersal event" scenario as a southern dispersion toward Western Europe during the earliest Oligocene, latter than the Eocene-Oligocene transition Grande-Coupure dispersal event through a northern pathway.

\section{GEOLOGICAL SETTING}

The Pčinja basin is located near the city of Vranje in southeastern Serbia, within Proterozoic and Palaeozoic metamorphic crystalline complexes of the Serbo-Macedonian Massif (Dimitrijević, 1997; Figure 1). The basin extends from Vranje-Bujanovac in the northwest into the Pčinja River valley in the southeast, over a distance of about $14 \mathrm{~km}$ (Terzin et al., 1977). It is filled with poorly exposed Eocene and few Oligocene sediments (up to $1500 \mathrm{~m}$ thick), which overlie Proterozoic crystalline rocks, Proterozoic and Palaeozoic granites, and Senonian rocks at places. As summarized by Dimitrijević and Dimitrijević (1981), Dimitrijević (1997), and de Bruijn et al. (2018), the basin fill consists of the following units. It begins with a unit (up to $750 \mathrm{~m}$ thick) of subaerially deposited Lepčince pyroclastics (tuffs and tuffites), found only along the eastern border of the basin. These are followed by an 80-300 m thick succession of pink to reddish pyroclastics with intercalated conglomerates deposited in ephemeral and braided streams (i.e. Koćurica Formation). The Koćurica Fm grades upward into 70-250 m thick grey non marine clastics (conglomerates, sandstones, siltstones, clays) known as the Vražja Crkva Forma- 


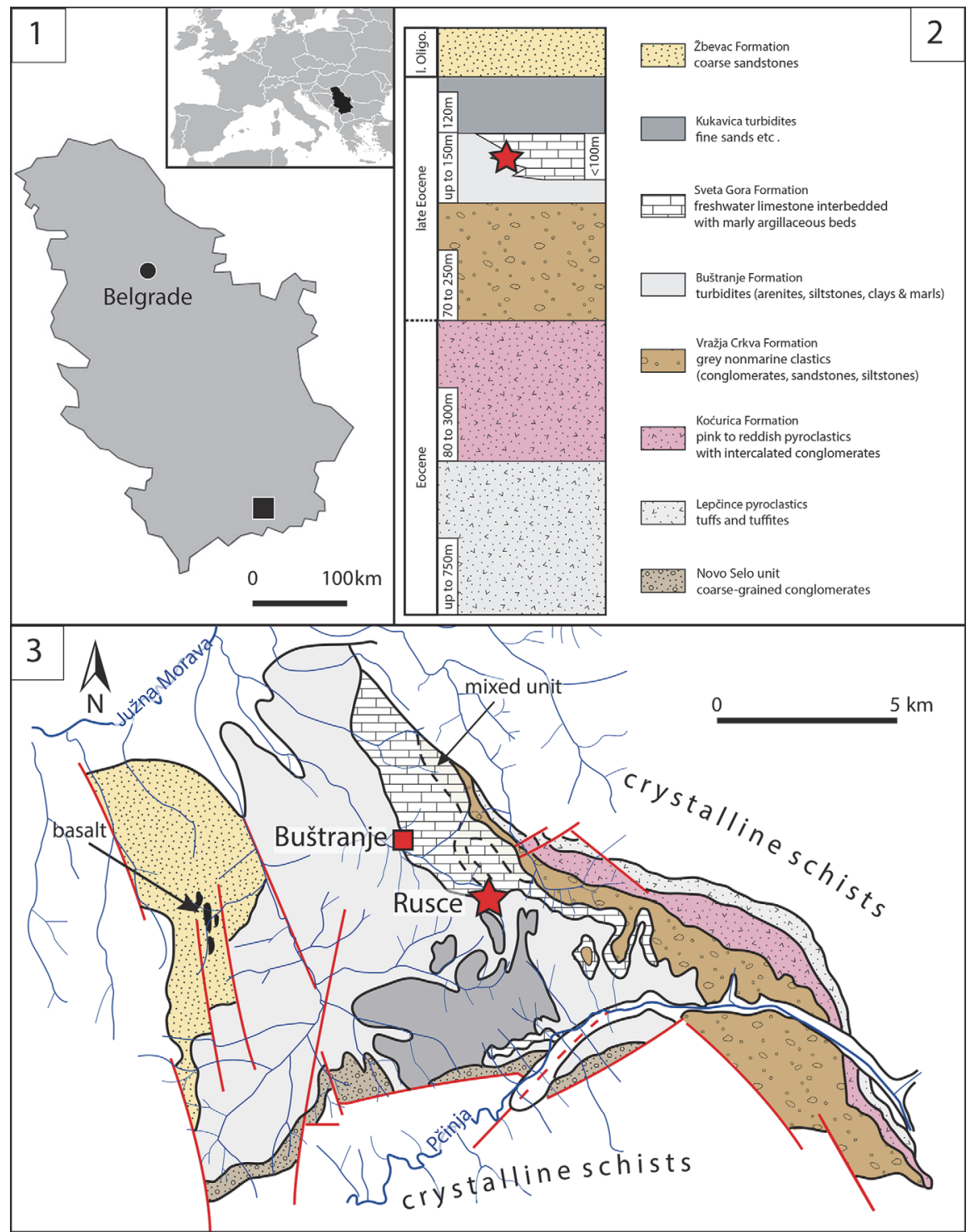

FIGURE 1. Geographical and geological setting of the Rusce locality. 1. Location of the Pčinja basin (black square) in Serbia; 2. Simplified lithologic section of the Pčinja basin with the approximate stratigraphic position of the Rusce Eocene ruminant (red star); 3. Simplified geological map of the Pčinja basin with the location of Rusce (red star: Rusce Eocene ruminant locality; red square: Buštranje Eocene mammal locality).

tion. The Buštranje Formation represents a turbiditic succession (arenites, silt, clays, and marls) up to $150 \mathrm{~m}$ thick, occurring nearly all over the Pčinja area. This succession resulted from a deepening of the depositional environment and bears spectacular traces of mass transport (i.e., slumping). In the southern central parts of the basin, the Buštranje $\mathrm{Fm}$ is followed by $120 \mathrm{~m}$ thick Kukavica turbidites, which represent the uppermost member in this region. Developed only on the northern fringe of the basin, the Sveta Gora Formation is a unit of freshwater limestone interbedded with marly argillaceous beds (up to $100 \mathrm{~m}$ thick), considered a lateral equivalent of the Buštranje Fm. The Novo Selo unit of coarse-grained conglomerates is present only in the southern margins of the basin. A coarse sandstone unit called Žbevac Formation is found in the southwestern part of the basin, and it is considered late Oligocene in age based on the fossil macroflora (Mihajlović, 1985). Numerous sedimentary structures within the basin indicate a paleotransport towards the southeast (Dimitrijević and Dimitrijević, 1981). Dimitrijević and Dimitrijević (1981, 1987) suggested that the Pčinja area was a part of a much larger Eocene-Oligocene basin, which 
included the Tikveš and Ovče Pole basins in FYR Macedonia (for more information on these basins see Stojanova and Petrov, 2012). Based on their studies of the fossil macroflora from the middle to upper course of the river Pčinja (i.e., south to southeastern part of the basin), Milaković (1960) and Pantić (1966) estimated a Paleogene age of the sediments from the basin. Furthermore, fossil plants from the Buštranje Formation described by Mihajlović (1985) suggested a late Eocene age. More recently, Marković et al. (2013) sampled argillaceous sandstones from several sites on the northern fringe of the Pčinja basin (including Rusce), and collected remains of small mammals by wet-screening of fossiliferous sediment samples. Although samples from Rusce did not yield any faunal remains, an assemblage from the nearby site of Buštranje, located northwest of Rusce, showed a late Eocene age for the Vražja Crkva Fm. New data from the region of Buštranje confirm a late Eocene age for the Sveta Gora Fm as well (de Bruijn et al., 2018).

The village of Rusce lies on top of thick upper Eocene strata (Terzin et al., 1977) formed by underwater sliding, consisting of marls, claystones, and sandstones (i.e., Buštranje Fm, according to Marković et al., 2013); massive or bedded limestones (i.e., Sveta Gora Fm), and a mixed horizon of shallow water clastites and limestones (i.e., transitional facia, according to de Bruijn et al., 2018; Vražja Crkva Fm, according to Marković et al., 2013), found north of Rusce; a turbidite horizon, consisting of marls, siltstones, and sandstones (i.e., Buštranje $\mathrm{Fm} /$ Kukavica turbidites), found to the south. All these formations are late Eocene in age. The ruminant fossil from Rusce was originally embedded in the matrix described as "greenishgrey micaceous sandstone" (Laskarev, 1939), most likely belonging to the transitional facies between the late Eocene terrestrial formations of Vražja Crkva and Sveta Gora (marked as mixed unit on Figure 1).

\section{MATERIAL AND METHODS}

The ruminant specimen from Rusce was an accidental find by a local resident, who donated the fossil in 1937 to the collection of the former Geological-paleontological Institute (University of Belgrade). Along with the large part of this collection, the specimen was then transferred to the Paleontological Collection of the Faculty of Mining and Geology (University of Belgrade). However, the specimen was lost under unclear circumstances. We were not able to locate it in any of the known collections, and we consider the fossil to be temporarily lost. We base our reassessment of the Rusce jaw fragment on the publication by Laskarev (1939). The original measurements have a precision of 0.5 to $1.0 \mathrm{~mm}$. The dental nomenclature follows Bärmann and Rössner (2011).

Abbreviations. MN - Mediterranean Mammal Neogene-Zone; Mya - Million years ago; $\mathrm{d}$ - deciduous; $\mathrm{p}$ - lower premolar; $\mathrm{m}$ - lower molar; NMNHS - National Museum of Natural History, Sofia, Bulgaria.

\section{SYSTEMATIC PALEONTOLOGY}

Ruminantia Scopoli, 1777

Bachitheriidae Janis, 1987

Bachitherium Filhol, 1882

Bachitherium cf. thraciensis Mennecart et al., 2018 Figure 2

Type specimen. NMNHS FM3320, Right mandible with $\mathrm{p} 2-\mathrm{m} 3$.

Type locality and horizon. Basal breccia-conglomerate-sandstone Formation at Sladun (Bulgaria), latest Bartonian or earliest Priabonian.

\section{Translated Original Description of the Rusce Specimen from Laskarev (1939)}

"The specimen from Rusce village represents a right mandible, attached to a firm sandstone slab. The original appearance is shown on figure 1 on table 1 [Figure 2 in this article]. As the jaw is cracked, we were forced to limit our preparation only to the dentition and the outer face; the inner face of the jaw was cleaned earlier, partly by natural processes.

For genus and species attribution of the Rusce jaw, only dental morphology and jaw and teeth metrics can be used. Based on the dental morphology, the jaw belongs to a juvenile form of deer, which preserves deciduous dentition d2-d4 and molars $\mathrm{m} 1-\mathrm{m} 3$. The jaw and teeth metrics are given on figure 1 [Figure 2 in this article], within the text. Molar morphology is typical for a deer, with four lunate (selenodont) cusps, of which the outer ones are pronouncedly bent, while the interior ones are only very weakly bent. The last molar $\mathrm{m} 3$ has a talonid $(t)$ [actually a posterior lobe surrounding the back fossa], an addition consisting of the third pair of selenodont cusps. The enamel surface is wrinkled on the upper border of the tooth. At the base of the last slope of the outer frontal selenodont cusps, there is a very characteristic transverse fold [i.e., external postprotocristid], with a weak pillar [i.e., ectostylid]. This is the so-called Palaeomeryx fold (Palaeomeryx-Falte), characteristic for the 

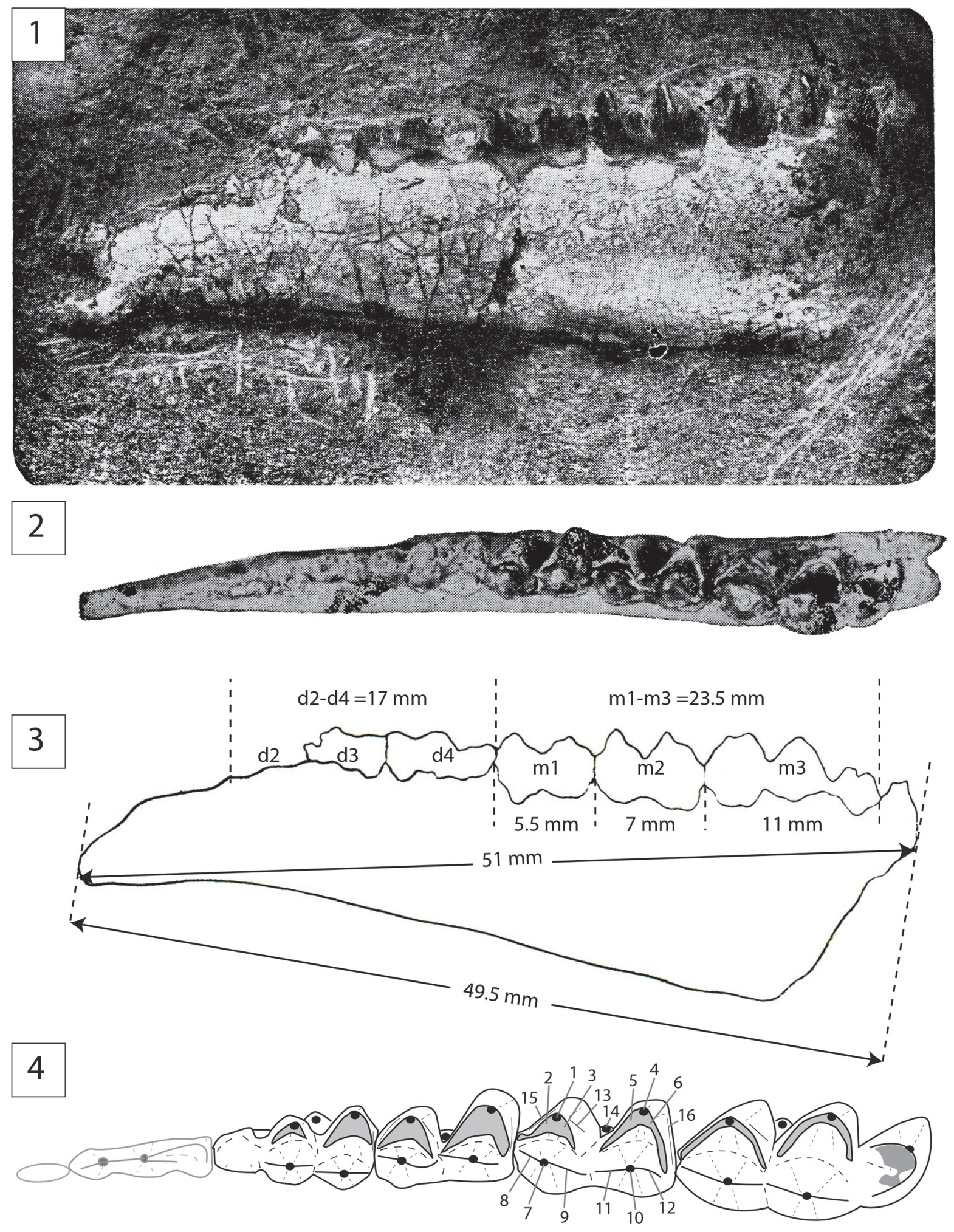

FIGURE 2. Original pictures and drawing of the Eocene ruminant from Rusce in lingual (1) and occlusal (2) views with associated measurements (3) (from Laskarev, 1939), and occlusal view interpretation (4). Dental nomenclature: 1, protoconid; 2, preprotocristid; 3, internal postprotocristid; 4, hypoconid; 5, prehypocristid; 6, posthypocristid; 7 , metaconid; 8, premetacristid; 9, postmetacristid; 10, entonconid; 11, preentocristid; 12, postentocristid; 13, external postprotocristid; 14 , ectostylid; 15 , anterior cingulid; 16 , posterior cingulid. The outline in grey (d2 and d3) is interpretative. 
older members of Cervulina (Amphitragulus, Palaeomeryx, Micromeryx), and gradually lost in younger members (Cervavus, Procervus). The first molar $\mathrm{m} 1$ is only weakly worn. The $\mathrm{m} 2$ shows only slight wear on the first two selenodont cusps. The $\mathrm{m} 3$ is unworn, and the talonid is not fully erupted from the jaw. This shows that our form is still juvenile, which is in agreement with the state of premolars, which are still deciduous. Deciduous dentition is characterized by the premolar $\mathrm{d} 4$, which displays three pairs of weak lunate cusps, where the last pair is the widest one (See Hofmann, 3, taf. XII, fig. 16-17, Dicrocerus). The penultimate deciduous molar [in fact deciduous premolar] has a wider posterior part, with an inward-folded enamel, and with the formation of the so-called "coulisse". In our specimen, the deciduous premolars are very worn (down to the root region), and soon to be replaced with permanent teeth. The $\mathrm{d} 4$ shows conspicuous enamel folding around the three pairs of cusps, typical for this tooth. The d3 morphology is obscured by wear. The d2 is completely broken. Aforementioned characteristics provide sufficient evidence to attribute our specimen to Cervulinae, the last of which survive on the Sunda Islands and in the Southeast Asia. According to Rütimeyer "among all the living Cervulina, the most hypsodont and smallest, Coassus rufinus [=Mazama americana] (i.e., muntjac), is the most closely related to Micromeryx. [Actually, Mazama americana is not a Muntiacini but an Odocoileini; see in e.g., Mennecart et al., 2017; Micromeryx is not a Cervidae, but a Moschidae see in e.g., Sánchez and Morales, 2008; Sánchez et al., 2010; Sánchez et al., 2015; Aiglstorfer et al., 2017].

The metrics of the jaw and dentition allow us to attribute the specimen to Micromeryx, which is differentiated from other members of Cervulinae by its small size. Concerning the species attribution, our specimen is close to the widely distributed species $M$. flourensianus Lartet. According to Rütimeyer (2, p. 92), M. flourensianus tooth row is $40 \mathrm{~mm}$ long (in our specimen it is $17+23.5=40.5$ $\mathrm{mm}$ ), premolar tooth row is 15 to $18 \mathrm{~mm}$ (in our specimen it is $17 \mathrm{~mm}$ ), molar tooth row is 22 $\mathrm{mm}$ (in our specimen it is $23.5 \mathrm{~mm}$ ). According to Hofmann (3, p. 67), m1-m3 $=21.5 \mathrm{~mm} \quad(23.5$ $\mathrm{mm}$ in our specimen), $\mathrm{m} 3$ length $=9.4 \mathrm{~mm}$, and $\mathrm{m} 3$ width $=4.6 \mathrm{~mm}$ (compared to 11 and $6 \mathrm{~mm}$ in our specimen, respectively). Therefore, dental metrics of the Rusce specimen fit with $M$. flourensianus metrics. Further, Rütimeyer (2, p. 92) claims that Lartet himself noticed "säulenförmige" [meaning column-shaped] teeth in $M$. flourensianus and "auf- falend stumpfe Zahnrelief" [meaning extraordinary acute tooth relief]. Hofmann notices that teeth crowns are positioned high above the jaw, higher than in other Cervulinae. These characteristics are also observed in our specimen.

Based on these observations, our specimen is close to M. flourensianus but also to Palaeomeryx $\mathrm{sp}$. Unfortunately, I was not able to procure the papers by Depéret and Filhol, necessary for this topic. Lartet described his $M$. flourensianus from Sansan, from the early [actually middle] Miocene. In Switzerland, this species was discovered in LaGrive St. Alban [in France, actually], from middle to upper [in fact middle] Miocene deposits. The species was also found in Steinheim (Würtemb.) and Eppelsheim (upper Miocene). In Styria, this species is found with the fauna characteristic for the middle and partly for the late Miocene. It seems to me that our Micromeryx flourensianus specimen allows for the dating of the lacustrine sediments from the Vranje basin [=Pčinja basin] to the late Miocene; it is quite possible that there are also middle Miocene sediments in the series. Thus, the Vranje lacustrine sediments were formed during the same interval as the Skopje lacustrine sediments and the lower-Congeria beds of the Leskovac basin. After the finds of Listriodon splendens, Hyotherium sömmeringi etc., our specimen witnesses the expansion of the rich mammalian Styrian-coal-bed fauna far to the Southeast."

\section{Taxonomical Attribution of the Rusce Specimen}

Some similarities do exist between the Rusce specimen and Moschidae (Micromeryx and Hispanomeryx), such as the small size of the mandible and the absence of $\mathrm{p} 1$ (Sánchez and Morales, 2008; Aiglstorfer et al., 2017). However, the Rusce specimen cannot be attributed to Micromeryx based on Laskarev's (1939) description. Most of the mentioned characters are plesiomorphic while typical moschid characters are missing from the specimen. Bovoidea, which includes Moschidae and Bovidae, is characterized by "the distally closed lower molars so typical" (Sánchez et al., 2010). In the specimen from Rusce, there is a space between the postentocristid and the posthypocristid on $\mathrm{m} 1$, a feature, which excludes this specimen from this Bovoidea and thus from Moschidae. Moreover, several other characters support the exclusion of this specimen from this family. Members of Moschidae possess a double crescentic third basin of the m3 (Sánchez and Morales, 2008; Sánchez et al., 2010; Sánchez et 
al., 2015; Aiglstorfer et al., 2017). Here we interpret this broken part to lack a well-developed entoconulid. In Moschidae, the molars are more laterally compressed with a relatively higher crown than in the Rusce mandible (Sánchez et al., 2010; Aiglstorfer et al., 2017). The ventral outline of the mandible is straight, which differs from Moschidae (Sánchez and Morales, 2008; Sánchez et al., 2010; Aiglstorfer et al., 2017). The lingual wall in the $\mathrm{m} 3$ is less flat than in moschids. The assertion that this specimen likely does not represent Moschidae is also supported by the age of the locality. The first estimation of the age of the Pčinja basin sediments was based entirely on the supposed presence of the "late Miocene" Micromeryx flourensianus (Laskarev, 1939). The Suoidea mentioned by Laskarev (1939) come from two other basins containing Miocene deposits - "Listriodon splendens" (=(Buno) Listriodon lockharti (Pomel) after Petronijević, 1967) from Kruševica near Aranđelovac (Central Serbia) and "Hyotherium sömmeringi" from Petrovac na Mlavi (Eastern Serbia) (Laskarev, 1936, 1937). However, the sediments in the area of Rusce have since been dated with certainty to the late Eocene (de Bruijn et al., 2018), and there are no trace of Neogene sediments in the basin. Furthermore, the latest phylogenetic analyses combining morphological and DNA characters, including fossil specimens, revealed that the clade Moschidae most likely originated during the early Miocene (Sánchez et al., 2015; Mennecart et al., 2017). The recently discovered MN4 Micromeryx (Alaburić and Radović, 2016) supports the hypothesis of the early Miocene moschid origin of Sánchez et al. (2015) and Mennecart et al. (2017). Thus, the Rusce specimen is necessarily much older than the probable first appearance of the Moschidae.

The specimen is a minute ruminant mandible, which preserves the tooth-row with d3-m3 in place and $\mathrm{d} / \mathrm{p} 2$ tooth socket. The $\mathrm{p} 1$ (if present) is not directly juxtaposed to the p2. Lophiomerycidae, Gelocidae and the Asiatic Gobiomeryx and Pseudomeryx do possess a $\mathrm{p} 2$ directly following the $\mathrm{p} 1$ without diastema in between. However, this is not the case for the Bachitheriidae ( $\mathrm{p} 1$ caniniform, Sudre, 1986, 1995; Geraads, 1987; Mennecart, 2012, 2015; Mennecart and Métais, 2015, Mennecart et al., 2011); Mosaicomeryx and Prodremotherium ( $\mathrm{p} 1$ absent, Mennecart and Métais, 2015), and the Praetragulidae ( $\mathrm{p} 1$ absent, Vislobokova, 1998, Vislobokova and Daxner-Höck, 2002, Métais and Vislobokova, 2007). Unfortunately, while the lingual view of the specimen embedded in matrix shows the presence of the $d 3$, this tooth is absent from the occlusal view (after the extraction from matrix). Nevertheless, the lingual view seems to show that two elongated cristids go towards the distal end of the $\mathrm{d} 3$ from the mesolabial conid, which is not observed in pecoran ruminants, in contrast to tragulines (Sudre, 1986; Mennecart, 2012, 2015). The molars possess anteriorly closed trigonids, confined by the anterior fusion of the premetacristid and the preprotocristid. This is different from the state seen in the molars of the Lophiomerycidae and stem Tragulidae (sensu Mennecart and Métais, 2015), which do not show a clearly developed and elongated premetacristid (Janis, 1987; Mennecart et al., 2011). The molars are laterally compressed and relatively high crowned in Asiatic Praetragulidae such as Praetragulus (Vislobokova, 1998; Vislobokova and Daxner-Höck, 2002); in contrast, they are more bunodont and low crowned in Bachitheriidae (Sudre, 1986; Mennecart, 2012, 2015; Mennecart et al., 2018). The mandible from Rusce possesses low crowned and relatively bunodont molars. The diastema anterior to the p2 is elongated, with strong dorso-ventral constriction just anterior to the p2. In Gelocidae (sensu Mennecart and Métais, 2015) and Paleogene Tragulidae the diastema is shortened (Mennecart et al., 2011). The constriction is not as marked in Praetragulidae (Vislobokova, 1998) as in Bachitheriidae (Sudre, 1986; Mennecart et al., 2011, 2012, 2018; Mennecart, 2015). The ventral outline of the mandible is straight, which differs from the Tragulidae, Lophiomerycidae, and Gelocidae, but is very similar to Bachitheriidae (Mennecart et al., 2011, 2012).

Based on this evidence, the specimen most probably belongs to the genus Bachitherium (the only genus of Bachitheriidae). Species-level distinctions within Bachitherium are based mainly on the inferred complexity of the lower permanent premolars, the tooth size, and limb bone proportions (Sudre, 1986, 1995; Mennecart et al., 2018). Unfortunately, lower permanent premolars and limb bone proportions are not known in the Rusce specimen. Nevertheless, its size is in agreement with those of the smallest Bachitheriidae, Bachitherium viretti Sudre, 1986, and $B$. thraciensis, which are the oldest bachitheriids known (the slight size differences in the measurements provided by Laskarev (1939) are most likely due to measurement error). The roughness of the enamel and the pronounced bunodont character of the cuspids are very similar to those observed in $B$. thraciensis (Mennecart et al., 2018). Currently this ruminant is 


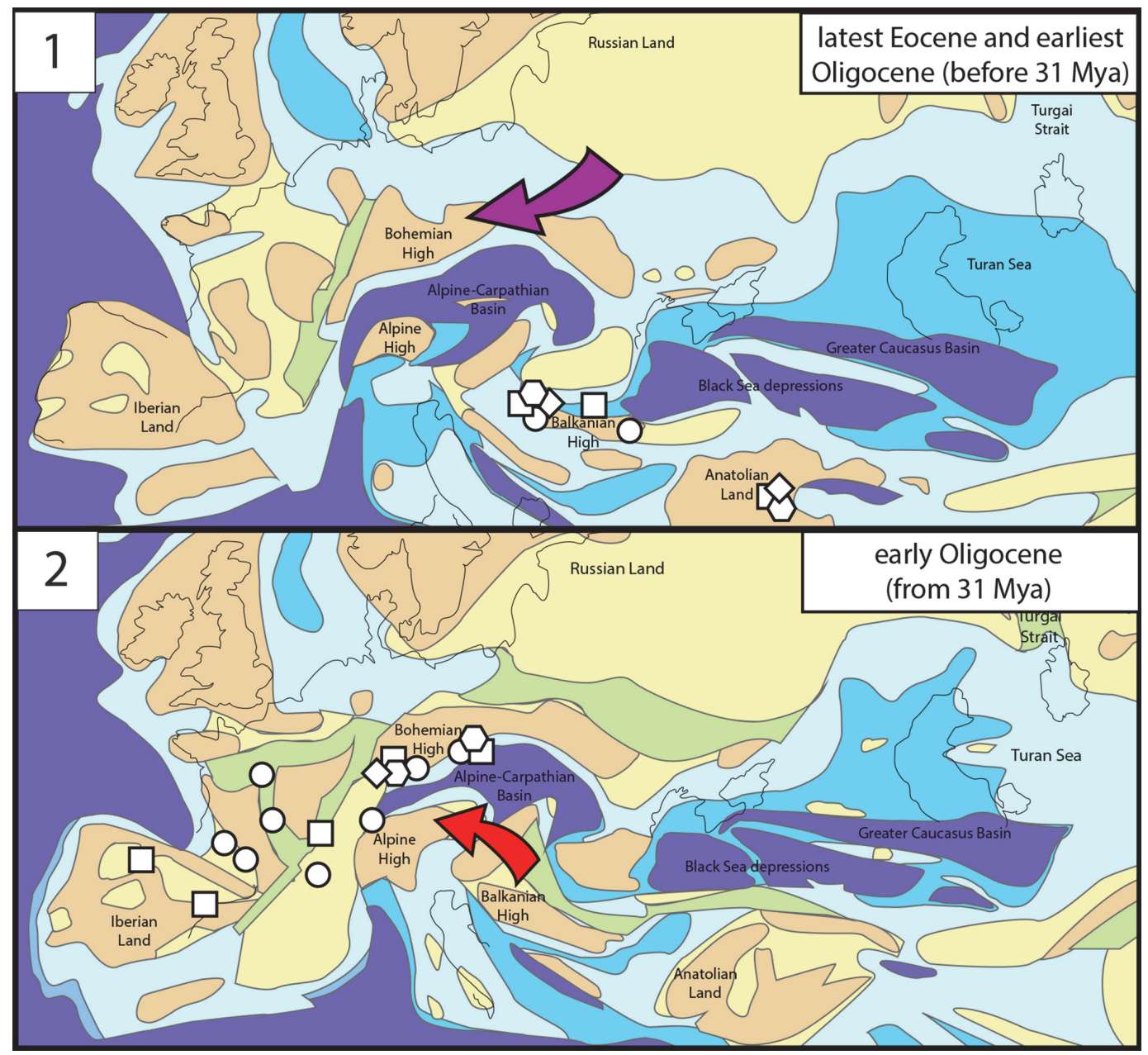

FIGURE 3. Paleobiogeography of the ruminant Bachitherium and associated Balkanic rodents absent from Western Europe during the late Eocene (mostly Priabonian) and earliest Oligocene (MP21-22) (1) and dispersing through Western Europe from ca. 31 Mya (MP23-24; 2). The purple arrow represents the Grande-Coupure dispersal event (MP21). The red arrow represents the Bachitherium dispersal event (MP23). Circle, Bachitherium spp.; square, Pseudocricetodon spp.; hexagon, Paracricetodon spp.; diamond, Melissiodontinae. The map has been modified from Mennecart et al. (2018) based on Popov et al. (2004). Biogeographical and biostratigraphical data are from Alvarez Sierra et al. (1999), Baciu and Hartenberger (2001), Martín-González et al. (2014), and de Bruijn et al. (2018).

only known from the late Eocene of Sladun (late Bartonian or early Priabonian, Bulgaria), which is similar in age to the sediment of the Rusce area (late Eocene). However, since we did not have a direct access to the specimen, we preferred to use open nomenclature and keep the ascription of the Rusce ruminant as Bachitherium cf. thraciensis.

\section{PALAEOBIOGEOGRAPHY OF THE LATE EOCENE AND OLIGOCENE MAMMALS FROM BALKANS}

The late Eocene Balkanic fauna is very different from the Western European ones. The oldest known European ruminants (two records of Bachitherium thraciensis) come from the late
Eocene "Balkanian High" (Figure 3). While older ruminants are known in Asia, none are currently described from Western Europe before the Grande-Coupure (Mennecart, 2012; Mennecart and Métais, 2015). Bachitherium is only known in Western Europe from MP23 (ca. 31 Mya, Mennecart et al., 2018). Similarly, the Balkanic Perissodactyla and rodent fauna compositions are drastically different from the contemporaneous Western European ones (i.e., prior to the GrandCoupure) (Heissig, 1979; de Bruijn et al., 2018; Mennecart et al., 2018; see Figure 3). The Perissodactyla and the 'Anthracotheriidae' Bakalovia present in the Balkans are typical Asiatic faunal elements (Böhme et al., 2013; Mennecart et al., 
2018). The Serbian Eocene rodent community is very diverse in Muridae (no less than 8 species, de Bruijn et al., 2018), similar to the situation observed in Anatolia (de Bruijn et al., 2003). This is the only rodent family currently described from the Eocene of Serbia (de Bruijn et al., 2018). This is in agreement with the rodent fauna observed in the Priabonian from Romania with the presence notably of the Muridae Pseudocricetodon sp. (Baciu and Hartenberger, 2001). Among the latest Eocene/ earliest Oligocene Muridae from Anatolia, we may recognize Pseudocricetodon and Paracricetodon, which are more primitive than the younger Western European ones (de Bruijn et al., 2003). The composition of the late Eocene rodent fauna from Serbia is unique in Europe with the co-occurrence of Melissiodontinae and a Spalacinae in Zvonce and Melissiodontinae, Pappocricetodontinae, Pseudocricetodon and Paracricetodon in Buštranje (de Bruijn et al., 2018). It is noteworthy that the oldest Pappocricetodontinae have been identified in the middle Eocene of Mongolia (Baciu and Hartenberger, 2001).

De Bruijn et al. (2018) observed that Eucricetodon, the oldest post-Grande-Coupure Central and Western European cricetid, is completely absent from the Serbian Oligocene faunas and may also be absent from Anatolia as suggested by de Bruijn et al. (2003), the Anatolian Eucricetodon may be in fact an Atavocricetodon.

Except for the Perissodactyla that did not survive the early Oligocene (Mennecart et al., 2018), the Eocene Balkan mammals are first recorded in Western Europe ca. 31 Mya (Figure 3), after the Grande-Coupure dispersal event that occurred ca. 33 Mya. Similarly to Bachitheriidae and Tragulidae, the oldest occurrence of Melissiodontinae in Western Europe is during the early Oligocene, at MP23 (Wessels et al., 2018). Pseudocricetodon and Paracricetodon may appear at MP22 in Germany at Herrlingen I (Baciu and Hartenberger, 2001). However, Dawson, (2003) supports that the
Pseudocricetodontinae also arrived in Western Europe at MP23.

Therefore, two different and diachronous pathways for east-west dispersal event(s) may be observed during the early Oligocene. The Northern Route, at the Eocene-Oligocene transition (ca. 33 Mya), is marked by the typical Grande-Coupure migrants. This event has been very well-documented for more than a century (Stehlin, 1909) and is marked by the presence of the first Western European ruminants (Gelocidae and Lophiomerycidae), Rhinocerotidae, and the rodent Eucricetodon. The dispersion via the Balkan Route occurred a little latter (ca. $31 \mathrm{Mya}$ ) and is responsible for the appearance of the ruminants Bachitheriidae and Tragulidae, and the rodents Melissiodontinae, Pseudocricetodon and Paracricetodon in Western Europe (Figure 3). During the Eocene, the Balkan region was isolated from Western Europe (Figure 3). The Paratethys Sea may have been a geographical barrier separating the Balkan area from Western Europe until the early Oligocene (Berger et al., 2005; Kocsis et al., 2014). The formation of a landbridge ca. 31 Mya allowed faunal exchanges between the Balkans and Western Europe known as Bachitherium dispersal event (Mennecart et al., 2018).

\section{ACKNOWLEDGMENTS}

K. Bradić-Milinović and L. Jović (Geological Survey of Serbia, Belgrade, Serbia) are thanked for their help with the geologic map, J. Lindal (Faculty of Medicine, University of Belgrade, Serbia) for proofreading the paper and his great help with English. B. Mennecart warmly thanks the Swiss National Science Foundation for granting the SNF Projects P300P2_161065 and P3P3P2_161066. I. Sànchez and M. Aiglstorfer are thanked for improving the manuscript through their review and the editors of Palaeontologia Electronica for the entire process.

\section{REFERENCES}

Aiglstorfer, M., Costeur, L., Mennecart, B., and Heizmann, E.P.J. 2017. Micromeryx? eiselei - a new moschid species from Steinheim am Albuch, Germany, and the first comprehensive description of moschid cranial material from the Miocene of Central Europe. PlosOne, 12(10):e0185679. https://doi.org/10.1371/journal.pone.0185679

Alaburić, S. and Radović, P. 2016. An early record of the moschid genus Micromeryx (Mammalia, Ruminantia), p. 141-148. In Marković, Z. and Milivojević, M. (eds.), Life on the 
Shore - Geological and Paleontological Research in the Neogene of Sibnica and Vicinity (Levač Basin, Central Serbia). Part 1. Natural History Museum in Belgrade, Serbia.

Alvarez Sierra, M.A., Daams, R., and Leáez-Campomanes, P. 1999. The late Oligocene rodent faunas of Canales (MP28) and Parrales (MP29) from the Loranca Basin, Province of Cuenca, Spain. Revista Espanola Paleontologia, 14:93-116.

Baciu, C. and Hartenberger, J.-L. 2001. Un exemple de corrélation marin-continental dans le Priabonien de Roumanie. Remarques sur la Grande Coupure. Comptes Rendus de l'Académie des Sciences de Paris, 333:441-446. https://doi.org/10.1016/S12518050(01)01659-7

Berger, J.-P., Reichenbacher, B., Becker, D., Grimm, M., Grimm, K., Picot, L., Storni, A., Pirkenseer, C., Derer, C., and Schaefer, A. 2005. Paleogeography of the Upper Rhine Graben (URG) and the Swiss Molasse Basin (SMB) from Eocene to Pliocene. International Journal of Earth Sciences, 94:697-710. https://doi.org/10.1007/s00531-005-0475-2

Böhme, M., Aiglstorfer, M., Antoine, P.-O., Appel, E., Havlik, P., Métais, G., The Phuc, L., Schneider, S., Setzer, F., Tappert, R., Ngoc Tran, D., Uhl, D., and Prieto, J. 2013. Na Duong (northern Vietnam) - an exceptional window into Eocene ecosystems from Southeast Asia. Zitteliana, 53:120-167. https://doi.org/10.5282/ubm/epub.19019

de Bruijn, H., Marković, Z., Wessels, W., Milivojević, M., and van der Weerd, A.A. 2018. Rodent faunas from the Paleogene of south-east Serbia. Palaebiodiversty and Palaeoenvironments, 98/3:441-458. https://doi.org/10.1007/s12549-017-0305-0.

de Bruijn, H., Ünay, E., Saraç, G., and Yïlmaz, A. 2003. A rodent assemblage from the Eo/ Oligocene boundary interval near Süngülü, Lesser Caucasus, Turkey. Coloquios de Paleontologia, 1:47-76.

Cote, S.M. 2010. Pecora Incertae Sedis, p. 731-739. In Werdelin, L. and Sanders, W.J. (eds.), Cenozoic Mammals of Africa. University of California Press, Berkley.

Dawson, M.R. 2003. Paleogene rodents of Eurasia, p. 97-126. In Reumer, J.W.F. and Wessels, W. (eds.), Distribution and Migration of Tertiary Mammals in Eurasia. Deinsea 10.

Dimitrijević, M.D. 1997. Geology of Yugoslavia. Geological Institute GEMINI, Special Publications, Belgrade. ISBN 86-7156-016-3:1-187.

Dimitrijević, M.N., and Dimitrijević, M.D. 1981. Sedimentologija pčinjsko-ovćepoljske grupe. Vesnik Zavoda za geološka i geofizicka istraživanja, serija A, 38/39:117-128. (In Serbian with English Summary)

Dimitrijević, M.N. and Dimitrijević, M.D. 1987. The Pčinja-Ovče Pole Group, p. 25-64. In Dimitrijević, M.N. and Dimitrijević, M.D. (eds.), The Turbiditic Basins of Serbia - Serbian Academy of Science and Arts, Monographs., Vol. DLXXVI. Department of Natural and Mathematical Sciences, Belgrade.

Geraads, D., Bouvrain, G., and Sudre, J. 1987. Relations phylétiques de Bachitherium Filhol, ruminant de l'Oligocène d'Europe occidentale. Palaeovertebrata, 17:43-73.

Groves, C. and Grubb, P. 2011. Ungulate Taxonomy. The Johns Hopkins University Press, Baltimore.

Heissig, K. 1979. Die hypothetische Rolle Südosteuropas bei den Säugetierwanderungen im Eozän und Oligozän. Neues Jahrbuch für Geologie und Paläontologie, Monatshefte, 2:8396.

Janis, C.M. 1987. Grades and clades in hornless ruminant evolution: the reality of the Gelocidae and the systematic position of Lophiomeryx and Bachitherium. Journal of Vertebrate Paleontology, 7:200-216. https://doi.org/10.1080/02724634.1987.10011653

Kocsis, L., Ozsvárt, P., Becker, D., Ziegler, R., Scherler, L., and Codrea, V. 2014. Orogeny forced terrestrial climate variation during the late Eocene- early Oligocene in Europe. Geology, 42(8):727-730. https://doi.org/10.1130/G35673.1

Laskarev, V. 1936. Miocenska fauna kičmenjaka iz okoline sela Kruševice (Bukulja). Annales Geologiques Peninsula Balkanique, 13:14-27. (In Serbian with French Summary)

Laskarev, V. 1937. O Hyotherium soemmeringi var. media H. v. M. iz okoline Petrovca na Mlavi. Annales Geologiques Peninsula Balkanique, 14:87-96. (In Serbian with French Summary)

Laskarev, V. 1939. Sur la trouvaille du Micromeryx flourensianus Lartet dans la Serbie Méridionale. Annales Geologiques Peninsula Balkanique, 16:60-64. (In Serbian with French Summary)

Marković, Z., Milivojević, M., and de Brujin, H. 2013. First recording of mammals in the Paleogene basin of Pčinja (Southern Serbia) - preliminary results. Reports of the Serbian Geological Society, for year 2012:43-50. (In Serbian with English Summary) 
Marković, Z., Wessels, W., van der Weerd, A.A., and de Bruijn, H. 2018. On a new diatomyid (rodentia, Mammalia) from the Paleogene of south-east Serbia, the first record of the family in Europe. Palaebiodiversty and Palaeoenvironments, 98/3:459-469. https://doi.org/10.1007/ s12549-017-0301-4

Martín-González, F., Freudenthal, M., Heredia, N., Martín-Suárez, E., and Rodrígez-Fernández, R. 2014. Palaeontological age and correlation of the Tertiary deposits of the NW Iberian Peninsula: the tectonic evolution of a broken foreland basin. Geological Journal, 49:15-27. https://doi.org/10.1002/gj.2484

Mennecart, B. 2012. The Ruminantia (Mammalia, Cetartiodactyla) from the Oligocene to the Early Miocene of Western Europe: systematics, palaeoecology and palaeobiogeography. GeoFocus 32:1-263. ISSN 1424-1463

Mennecart, B. 2015. The European ruminants during the "Microbunodon Event" (MP28, latest Oligocene): impact of climate changes and faunal event on the ruminant evolution. PlosOne, 10(2):e0116830. https://doi.org/10.1371/journal.pone.0116830

Mennecart, B., Becker, D., and Berger, J.-P. 2011. Iberomeryx minor (Mammalia, Artiodactyla) from the Early Oligocene of Soulce (Canton Jura, NW Switzerland): systematics and palaeodiet. Swiss Journal of Geosciences, 104(Suppl. 1):S115-S132. https://doi.org/ 10.1007/s00015-010-0034-0

Mennecart, B., Becker, D., and Berger, J.-P. 2012. Mandible shape of ruminants: between phylogeny and feeding habits, p. 205-229. In Mendes, E.D. (ed.), Ruminants: Anatomy, Behaviour and Diseases. Nova, New York.

Mennecart, B., DeMiguel, D., Bibi, F., Rössner, G.E., Métais, G., Neenan, J.M., Wang, S., Schultz, G., Müller, B., and Costeur, L. 2017. Bony labyrinth morphology clarifies the origin and evolution of deer. Scientific Reports, 7:13176. https://doi.org/10.1038/s41598-01712848-9

Mennecart, B., Geraads, D., Spassov N., and Zagorchev, I. 2018. Discovery of the oldest European ruminant in the late Eocene of Bulgaria: Did tectonics influence the diachronic development of the Grande Coupure. Palaeogeography, Palaeoclimatology, Palaeoecology, 498:1-8. https://doi.org/10.1016/j.palaeo.2018.01.011

Mennecart, B. and Métais, G. 2015. Mosaicomeryx gen. nov., a ruminant mammal from the Oligocene of Europe, and the significance of "gelocids". Journal of Systematic Palaeontology, 13(7):581-600. https://doi.org/10.1080/14772019.2014.948505

Métais, G. and Vislobokova, I. 2007. Basal ruminants, p. 189-212. In Prothero, D.R. and Foss, S.E. (eds.), The Evolution of Artiodactyls. The Johns Hopkins University Press, Baltimore.

Milaković, B. 1960. Paleogena fosilna flora iz šire oblasti srednjeg toka Pčinje. Glasnik prirodnjačkog muzeja, serija A, 13:29-39. (In Serbian with English Summary)

Mihajlović, Đ.S. 1985. Palaeogene fossil flora of Serbia. Annales Geologiques Peninsula Balkanique, 49:399-434. (In Serbian with extended English summary)

Pantić, N. 1960. Paleogena fosilna flora iz gornjeg toka Pčinje (SR Srbija). Vranjski glasnik, 2:339-347. (In Serbian)

Petronijević, Z. 1967. Srednjomiocenska i donjosarmatska (štajerska) fauna sisara Srbije. Palaeontologia Jugoslavica, 7:1-117. (In Serbian with German summary)

Popov, S.V., Rogl, F., Rozanov, A.Y., Steininger, F.F., Shcherba, I.G., and Kovac, M. 2004. Lithological-Paleogeographic maps of Paratethys 10 Maps Late Eocene to Pliocene. Courier Forschungsinstitut Senckenberg, 250:1-46.

Sánchez, I.M., Cantalapiedra, J.L., Ríos, M., Quiralte, V., and Morales, J. 2015. Systematics and Evolution of the Miocene Three-Horned Palaeomerycid Ruminants (Mammalia, Cetartiodactyla). PlosONE, 10(12):e0143034. https://doi.org/10.1371/journal.pone. 0143034

Sánchez, I.M., Domingo, M.S., and Morales, J. 2010. The genus Hispanomeryx (Mammalia, Ruminantia, Moschidae) and its bearing on musk-deer phylogeny and systematics. Palaeontology, 53(5):1023-1047. https://doi.org/10.1111/j.1475-4983.2010.00992.x

Sánchez, I. M. and Morales, J. 2008. Micromeryx azanzae sp. nov. (Ruminantia; Moschidae) from the middle-upper Miocene of Spain, and the first description of the cranium of Micromeryx. Journal of Vertebrate Paleontology, 28(3):873-885. https://doi.org/10.1671/ 0272-4634(2008)28[873:MASNRM]2.0.CO;2

Stehlin, H.G. 1909. Remarques sur les faunules de Mammifères des couches éocènes et oligocènes du Bassin de Paris. Bulletin de la Société Géologique de France, 4(9):488-520.

Stojanova, V. and Petrov, G. 2012. Correlation of the lithostratigraphic profiles in the Paleogene basins in the Republic of Macedonia, p. 99-100. In Proceedings of Bulgarian Geological 
Society, National Conference with International Participation B Geosciences 2012. Sofia, Bulgaria.

Sudre, J. 1986. Le genre Bachitherium Filhol 1882 (Mammalia, Artiodactyla): diversité spécifique, phylogénie, extension chronologique. Comptes Rendus de l'Académie des Sciences de Paris, 303(8):749-754.

Sudre, J. 1995. Le Garouillas et les sites contemporains (Oligocène,MP 25) des Phosphorites du Quercy (Lot, Tar-et-Garonne, France) et leurs faunes de Vertébrés. 12. Artiodactyles. Palaeontographica (A), 236:205-256.

Terzin, V., Rakić, M.O., Bodić, D., Vukanović, M., Dimitrijević, M., Dimitrijević, M.N., Karajicić, I.J., and Vukanović, M. 1977. Mapsheet Vranje (K 34-54) and Explanatory booklet. Savezni geološki zavod, Belgrade. (In Serbian with short English summary)

Tissier, J., Becker, D., Codrea, V., Costeur, L., Farcas, C., Solomon, A., Venczel, M., and Maridet O. 2018. New data on Amynodontidae (Mammalia, Perissodactyla) from Eastern Europe: phylogenetic and palaeobiogeographic implications around the Eocene-Oligocene transition. PlosOne, 13(4):e0193774. https://doi.org/10.1371/journal.pone.0193774

van der Made, J. 1999. Intercontinental relationship Europe-Africa and the Indian Subcontinent, p. 457-472. In Rössner, G.E. and Heissig, K. (eds.), The Miocene Land Mammals of Europe. Verlag Dr Friedrich Pfeil, Munich, Germany.

van der Weerd, A.A., de Bruijn, H., Marković, Z., and Wessels, W. 2018. Paracricetodontinae (Mammalia, Rodentia) from the late Eocene and early Oligocene of south-est Serbia. Palaebiodiversty and Palaeoenvironments, 98/3:489-508. https://doi.org/10.1007/s12549017-0317-9

Vislobokova, I.A. 1997. Eocene-early Miocene ruminants in Asia, p. 213-215. In Aguilar, J.-P., Legendre, S., and Michaux, J. (eds.), Actes du Congrès BiochroM'97, Mémoires et Travaux. L'école Pratique des Hautes Etudes, Institut de Montpellier, Montpellier, France.

Vislobokova, I. 1998. A new representative of the Hypertraguloidea (Tragulina, Ruminantia) from the Khoer-Dzan locality in Mongolia, with remarks on the relationships of the Hypertragulidae. American Museum Novitates, 3225:1-24.

Vislobokova, I. and Daxner-Höck, G., 2002. Oligocene-Early Miocene ruminants from the Valley of Lakes (Central Mongolia). Annalen des Naturhistorisches Museums in Wien, 103A:213235.

Webb, D.S. 1998. Hornless ruminants, p. 463-476. In Janis, C.M., Scott, K.M., and Jacob, L.L (eds.), Evolution of Tertiary Mammals of North America, Volume 1: Terrestrial Carnivores, Ungulates, and Ungulatelike Mammals. Cambridge University Press, Cambridge.

Wessels, W., van der Weerd, A.A., de Bruijn, H., and Marković, Z. 2018. New Melissiodontidae (Mammalia, Rodentia) from the Paleogen of south-east Serbia. Palaebiodiversty and Palaeoenvironments, 98/3:471-487. https://doi.org/10.1007/s12549-017-0311-2 